\title{
The French New Right's Quest for Alternative Modernity
}

\author{
Tamir Bar-On \\ Department of International Relations and Humanities, Tecnológico de Monterrey \\ (Monterrey Institute of Technology and Higher Education), Campus Querétaro, Mexico \\ E-mail: tbaron@itesm.mx; tamir.baron@gmail.com
}

\begin{abstract}
The purpose of this paper is to offer a new interpretation of the French nouvelle droite (ND New Right). The author argues that the ND is a heterogeneous, pan-European "school of thought" consisting of different ideological tendencies. Yet, contrary to the predominant interpretation of the revolutionary right as "anti-modern" and "reactionary", key ND thinkers, including its leader Alain de Benoist, are wedded to a revolutionary, alternative modernist conception of politics which is neither liberal nor socialist. The paper in question begins by assessing whether the ND is a fascist movement. The paper then focuses on Roger Griffin's "ideal type" definitions of modernism and fascism to argue that ND theorists fit within modernist and fascist frameworks with roots in the late $19^{\text {th }}$ and $20^{\text {th }}$ centuries. The ND's modernist framework seeks to "rescue" contemporary Europe from its profound "decadence" and "crises" in a seemingly contradictory ideological pastiche (i.e., "mazeway resynthesis") combining premodern, modern, and postmodern political and philosophical influences.
\end{abstract}

Keywords

French New Right; nouvelle droite; pan-Europeanism; modernism; fascism; alternative modernity; mazeway resynthesis; Roger Griffin

\section{Introduction}

This paper focuses on the French nouvelle droite (ND - New Right), which is today a pan-European transnational right-wing movement that did not exist before 1968 and saw its apogee in French media and academic debates of the late 1970s. ${ }^{1}$ Led by French intellectual Alain de Benoist (b. 1943), the ND is a

\footnotetext{
1) My Where Have All The Fascists Gone? (Aldershot: Ashgate, 2007) reviews the most important scholarship on the ND in French and English. Please note that there is also substantive body of research on the French ND and German Neue Rechte in German.

See also: Tomislav Sunic. Against Democracy and Equality: The European New Right. New York: Peter Lang, 1990; Tamir Bar-On. "Transnationalism and the French nouvelle droite." Patterns of Prejudice, 45 (2011) 4, 199-223; Ibid. "Understanding Political Conversion and Mimetic Rivalry." Totalitarian Movements and Political Religions, 10 (2009) 3, 241-264; Ibid. "Fascism to the Nouvelle
} 
"cultural school of thought" (école de pensée) ${ }^{2}$ with various ideological tendencies from modernist to more Traditionalist currents, ${ }^{3}$ all wedded to the cultural terrain and the battle of ideas to differentiate themselves from extreme rightwing political parties and ultra-nationalist, violent extra-parliamentary movements.

Given de Benoist's vast writing production, the French intellectual spread ND ideas beyond a narrow elite circle. De Benoist's ideas are today disseminated throughout Europe by other intellectuals, including Marco Tarchi in Italy, Michael Walker and Troy Southgate in England, Robert Steuckers in Belgium, and Aleksandr Dugin in Russia. ND-friendly intellectuals can also be found in Germany, Holland, Spain, Croatia, Romania, Poland, and other European countries. De Benoist acted as the ND's key transnational messenger within Europe. For de Benoist and the ND, a web of shared networks (e.g., think-tanks, journals, conferences, etc.) and beliefs (e.g., the extreme and revolutionary right-wing shift from narrow nationalism to a new "European home") created processes which transcended the centrality of state actors. While de Benoist and the ND recognize "the extraordinary importance" of states and empires, they also pay attention to "networks, processes, beliefs, and institutions that transcend these politically defined spaces." ${ }^{\prime 4}$ The ND reasoned that major changes in belief systems across nations eventually yield revolutionary political changes throughout Europe.

For the ND, revolutionary political changes needed radical intellectuals with a mission to destroy liberalism. De Benoist cemented ties with revolutionary right-wing intellectuals throughout Europe in order to spread ND ideas beyond France. Currently a political science professor at the University of Florence, Marco Tarchi is considered the leading figure of the Italian Nuova Destra (New Right). He has also been a Visiting Professor at the University of Turku in Finland. The Nuova Destra was born in 1974 after intellectual exchanges with the French ND. ${ }^{5}$ Tarchi was a former youth leader of the neofascist Movimento Sociale Italiano (MSI - Italian Social Movement) and the editor of a journal, Diorama letterario, which modeled itself on French ND journals created by de Benoist. Walker was a former organizer with the British

Droite: The Dream of Pan-European Empire." Journal of Contemporary European Studies, 16 (2008) 3, 327-345; Ibid. "The Ambiguities of the Nouvelle Droite, 1968-1999." The European Legacy, 6 (2001) 3, 333-351.

2) Anne-Marie Duranton-Crabol. Visages de la Nouvelle Droite: le GRECE et son histoire. Paris: Presses de la Fondation nationale des sciences politiques, 1988.

3) Stéphane François. 2009. "Contre Le Monde Moderne: La Nouvelle Droite et La Tradition." Etudes et analyses, 21 (2009) juillet: 1-12; Ibid. Les Néo-paganismes et la Nouvelle Droite: pour une autre approche. Milan: Archè, 2009.

4) Sven Beckert. "Symposium 'AHR Conversation: On Transnational History'” The American Historical Review , 111 (2006) 5, 1459.

5) Bar-On. Where Have All The Fascist Gone?, 145 
National Front (BNF) in central London, sheltered the Italian neo-fascist terrorist Roberto Fiore in the 1980s, and created an ND-influenced journal, The Scorpion. Inspired by the French ND, Troy Southgate is an avowed "National Anarchist" and created the New Right movement in London in 2005 and later the journal New Imperium. Steuckers is considered the head of the Belgian New Right, belonged to GRECE, ${ }^{6}$ and is the founder of a journal, Vouloir, which was influenced by de Benoist's ND. Steuckers accused the ND of being too metapolitical and later supported the anti-immigrant political party Vlaams Blok (Flemish Bloc).

The geopolitical thinker Aleksandr Dugin (b. 1962) is viewed today as one of the greatest proponents of Russian expansionism, ultra-nationalism, fascism, and Eurasianism (i.e., a European-Asian alliance against the neo-liberal USA) along imperial lines. ${ }^{7}$ Dugin is close to the National Bolshevik Party and Eurasia Movement, which is said to have the ear of leading Russian politicians and Prime Minister Vladimir Putin's anti-democratic and hypernationalist government. ${ }^{8}$ The Russian intellectual has important ties to the executive and legislative branches of the Russian state, as well as a large following among Russian academics, journalists, publicists, and activists. After contacts were established with de Benoist in Moscow in the early 1990s, Dugin created a Russian New Right journal, Elementy, modeled on the French ND's Éléments. De Benoist briefly served on the editorial board of Elementy, but resigned because he was troubled by Dugin's open ultra-nationalism and anti-Semitism. In more recent

6) GRECE is the French acronym for the key ND think-tank Groupement de recherche et d'études pour la civilisation européenne (Research and Study Group for European Civilization). The French acronym GRECE means Greece and GRECE pined for the paganism of Greek antiquity. Founded legally in 1969 by Alain de Benoist and about forty other intellectuals, GRECE followed French neo-fascist Maurice Bardèche (1907-98) in seeking to avoid the "outdated vocabulary" of the fascist past. See Bar-On, Where Have All The Fascists Gone?, 30-32.

7) On the question of whether Dugin is a fascist and a debate about Griffin's "fascist minimum", see the special bilingual (English and German) issue of Deliberation, Knowledge, Ethics, 15 (2004) 3, which takes as its starting point a piece by Roger Griffin entitled "Fascism's new faces (and new facelessness) in the 'post-fascist' epoch." On Dugin's purported fascism, see the pieces by Andreas Umland and A. James Gregor, with the latter arguing that Dugin is not a fascist and the former insisting the Russian thinker is a fascist.

See also: Alan Ingram. "Alexander Dugin: Geopolitics and Neo-Fascism in Post-Soviet Russia," Political Geography, 20 (2001) 8, 1029-1051; Marlene Laurelle. "Aleksandr Dugin: a Russian Version of the European Radical Right." Kennan Institute Occassional Paper \#294 (2006). http:// www.scribd.com/mstolpness\% $3 \mathrm{C}_{3} \%$ A6ter/d/48735479-Aleksandr-Dugin-A-Russian-Version -of-the-European-Radical-Right-by-Marlene-Laruelle. Accessed January 22, 2012; Andreas Umland. "Fascist Tendencies in Russia's Political Establishment." Russian Analytical Digest, 60 (2009), 13-17; Ibid. The Nature of Russian 'Neo-Eurasianism': Approaches to Aleksandr Dugin's Post-Soviet Movement of Radical Anti-Americanism. Armonk, New York: M.E. Sharpe, 2009.

8) Anton Shekhovtsov. "Aleksandr Dugin's Neo-Eurasianism: The New Right à la Russe." Religion Compass, 3 (2009) 4, 697-716; Ibid. "The Palingenetic Thrust of Russian Neo-Eurasianism: Ideas of Rebirth in Aleksandr Dugin's Worldview." Totalitarian Movements and Political Religions, 9 (2008) 4, 491-506. 
years, de Benoist visited and spoke at the prestigious Moscow State University where Dugin is a Professor and Acting Chair of International Sociology. In the new millennium, Dugin has also met several ND thinkers in Paris, Antwerp, and London. ${ }^{9}$

Today the ND's influence, particularly de Benoist's writings, can be felt on diverse publications such as Telos and The Occidental Quarterly (USA), The Mankind Quarterly and The Scorpion (United Kingdom), Punto y coma and Hespérides (Spain), Neue Anthropologie (Germany), and Maiastra (Romania). According to Minkenberg, ${ }^{10}$ the ND is intellectually close to the German Neue Rechte, the New Right in the United Kingdom, Nieuw Rechts in the Netherlands and Flanders (Belgium), Forza Nuova in Italy, Imperium Europa in Malta, and New Right forces in the USA connected to Paul Weyrich and the Free Congress Foundation. Woods ${ }^{11}$ has demonstrated how the German New Right was troubled by its own special vocation connected to Germany's extraordinary Nazi genocidal past, but was nonetheless influenced by the ND and especially de Benoist, including his positive reading of some pro-Nazi Conservative Revolution (CR) thinkers such as Carl Schmitt (1888-1985), project of cultural hegemony, critique of modernity, cultural pessimism, fear of multicultural societies, and alarmist predictions about rising non-Western powers due to the "demographic explosion" outside Europe.

In 1999, de Benoist and Charles Champetier (a former head of the French ND's youth wing) published the ND manifesto, "The French New Right in the Year 2000". ${ }^{22}$ The manifesto was translated into English, German, Italian, Spanish, Dutch, Danish, and Hungarian by ND or ND-friendly journals, including Telos (USA), Junge Freiheit (Germany), Diorama letterario (Italy), Hespérides (Spain), TeKoS (Belgium), and Nomos (Denmark). The manifesto was the first major comprehensive ND document in the new millennium highlighting the ND's appraisal of the modern (or postmodern) world, philosophical foundations, and positions on contemporary issues such as immigration, democracy, ecology, supranational organizations, and the market system.

De Benoist has served as the key messenger of ND ideas within France and throughout Europe, as well as the USA, Canada, Australia, New Zealand, and Latin America. For example, Disenso is an Argentinean journal edited by

\footnotetext{
9) Anton Shekhovtsov and Andreas Umland. "Is Dugin a Traditionalist? 'Neo-Eurasianism' and Perennial Philosophy." The Russian Review, 68 (2009) 4, 666.

10) Michael Minkenberg. " The Renewal of the Radical Right: Between Modernity and Antimodernity." Government and Opposition, 35 (2000) 2, 170-188.

i1) Roger Woods. Germany's New Right As Culture and Politics. Basingstoke, UK: Palgrave MacMillan, 2007, 25-64.

12) Charles Champetier and Alain de Benoist. "La Nouvelle Droite de l'an 200o." Éléments, 94 (1999) février, 10-23. See also : Ibid. "The French New Right In The Year 200o." http://home .alphalink.com.au/ radnat/debenoist/alaing.html. Accessed October 31, 2011.
} 
Alberto Buela, which is influenced by ND ideas. Disenso is distributed throughout Latin America. Australia and New Zealand promotes ND ideas through the blog New Right Australia/New Zealand..$^{13}$

In addition, the ND is technologically savvy. Alain de Benoist's website ${ }^{14}$ provides translations of his works in eight European languages: French, English, German, Italian, Spanish, Dutch, Polish, and Czech. There are also websites for GRECE $^{15}$ and Éléments, ${ }^{16}$ as well as an internet presence for numerous ND-friendly journals from Junge Freiheit ${ }^{17}$ in Germany to Diorama letterario ${ }^{18}$ in Italy. An ND variant of Wikipedia, Metapedia, ${ }^{19}$ was created by ND supporters in Sweden to disseminate ND ideas worldwide.

The ND valorizes an illiberal, pagan political legacy, which is antagonistic to counter-revolutionary, conservative, and Anglo-American (neo-liberal) rightwing traditions, and uneasy about fascism. ${ }^{20}$ It was accused of "fascism with a human face" by elements of the liberal-left intelligentsia in France in two mass media "storms" in 1979 and 1993-4. A 1994 Le Monde "Appeal to Vigilance" warning of the "danger" of ND ideas and its "alarming" dialogue with communist intellectuals was signed by 1500 European intellectuals. ${ }^{21}$

The ND's ideological syncretism and its "leftist" drift beginning in the 1980 s puzzled political commentators. For example, ND leader Alain de Benoist claimed that he would vote for the French Communists in the 1984 European elections, while one French ND expert argued that in the early 1980s the ND shifted from communism to liberalism as the "main enemy".22 Yet, using Norberto Bobbio's ${ }^{23}$ inequality-equality schism to position right and left, ND thinkers are more on the right than left because they reject administrative and legal equality, the republican heritage of the French Revolution, and the notion that humans are equal in terms of their fitness to rule. ${ }^{24}$

\footnotetext{
13) http://newrightausnz.blogspot.com/ Accessed June 18, 2010.

14) http://www.alaindebenoist.com/ Accessed January 20, 2012.

15) http://grece-fr.com/ Accessed February 3, 2012.

16) http://grece-fr.com/?category_name=elements Accessed February 3, 2012.

17) http://www.jungefreiheit.de/ Accessed January 20, 2012.

18) http://www.diorama.it/ Accessed January 20, 2012.

19) http://www.metapedia.org/ Accessed February 3, 2012.

${ }^{20)}$ Louis Pauwels. France-Soir (29 mars). 1979.

21) Frank Adler. "Left Vigilance in France." Telos, 98-99 (1993/94) Winter-Spring, 23-33; Paul Piccone. "Confronting the French New Right: Old Prejudices or a New Political Paradigm?" Telos, 98-99 (1993/94) Winter-Spring, 3-23; Bar-On. Where Have All The Fascists Gone?, 11.

${ }^{22)}$ Duranton-Crabol, 46; Alain de Benoist. “L'ennemi principal." Éléments, 41 (1982) mars-avril.

${ }^{23)}$ Norberto Bobbio. Left and Right:The Significance of a Political Distinction. Chicago: University of Chicago Press, 1996.

24) Alain de Benoist. Bibliographie générale des droites françaises (four volumes). ParisCoulommiers: Dualpha, 2004-2005 ; Ibid. Au-delà des droits de l'homme. Pour défendre les libertés. Paris: Krisis, 2004; Ibid. "Democracy Revisited: The Ancients And The Moderns." The Occidental Quarterly, 3 (2003) 2, 47-58; Ibid. Vu de droite. Paris: Copernic, 1979.
} 


\section{The ND and fascism}

In Where Have All The Fascists Gone? I examined the relationship of ND thinkers to fascism, extreme right-wing political parties, and the revolutionary rightwing milieux. First I pointed out that both minimalist (one or few criteria) and maximalist (many criteria) typological descriptions and definitions of fascism must be examined, if we are to understand fascism and then attempt to relate fascism to the ND. Second, with such a complex subject like fascism, my preference is for maximalist descriptions and understanding how fascism is simultaneously an ideology, movement, and regime in power.

A minimalist definition was proposed by Zeev Sternhell ${ }^{25}$, who posited that fascism was a synthesis of ultra-nationalism and Marxist socialist revisionism. The English historian of ideas Roger Griffin once defined fascism as "a palingenetic form of populist ultra-nationalism.. ${ }^{26}$ Both definitions can be applied to the ND, with the caveat that the ND's "ultra-nationalism" is today framed as "ultra-regionalism" through the notion of a "Europe of a hundred flags". Yet, this "ultra-regionalism" conceives of the rebirth of hundreds of homogeneous ethnically "pure" states within a larger post-liberal, pan-European framework. ${ }^{27}$

I now turn to maximalist definitions of fascism. R.O. Paxton defined fascism in a manner that would today omit the ND because they reject the cult of violence and the imperialist notion of "external expansion":

"A form of political behaviour marked by obsessive preoccupation with community decline, humiliation, or victimhood and by compensatory cultures of unity, energy, and purity, in which a mass-based party of committed nationalist militants, working in uneasy but effective collaboration with traditional elites, abandons democratic liberties and pursues with redemptive violence and without ethical or legal restraints goals of internal cleansing and external expansion., ${ }^{28}$

Stanley Payne's typological description of fascism along the lines of ideology and goals, the fascist negations, and style and organization applies merely to inter-war fascist movements. ${ }^{29}$ However, in an earlier work, Payne not only used a typological description of fascism, but also applied it to post-war fascist movements outside of Europe, arguing that Argentina's Peronism (1946-55)

\footnotetext{
${ }^{25)}$ Zeev Sternhell et al. The Birth of Fascist Ideology. Princeton, New Jersey: Princeton University Press, 1994; Zeev Sternhell. Neither Right, Nor Left: Fascist Ideology in France. Berkeley, California: University of California Press, 1986.

26) Roger Griffin, ed. Fascism. Oxford: Oxford University Press, 1995, 9.

${ }^{27)}$ Alberto Spektorowski. "Ethnoregionalism, Multicultural Nationalism and the Idea of a European Third Way." Studies in Ethnicity and Nationalism, 7 (2007) 3, 45-63.

${ }^{28)}$ R.O. Paxton. The Anatomy of Fascism. New York: Alfred A. Knopf, 2004, 218.

29) Stanley Payne. A History of Fascism, 1914-1945. London: UCL Press, 1995, 7.
} 
"had most but not all the characteristics of European fascism." ${ }^{30}$ If we were to borrow Payne's description of fascism for post-war movements, the ND meets many but not all of the characteristics of fascism. So, for example, ND doyen Alain de Benoist has criticized numerous characteristics of fascism, including the charismatic leadership principle, the party army, the aim of totalitarianism, colonial expansion, and nationalism. On the other hand, the ND meets all of fascism's negations (i.e., anti-liberalism, anti-communism, and anti-conservatism). In addition, the ND longs for a corporatist political framework, a secular, "spiritual", and revolutionary new order, and ethnically homogenous political communities - all goals of inter-war fascists.

Third, I argued that sectors of the post-war revolutionary right-wing milieu, from which the ND's thinkers' originated, needed to engage in "cave dwelling" if they were to survive in a liberal, "anti-fascist" era. That is, if fascism or "crypto-fascism" was to make a comeback, it needed to go underground akin to cave dwellers to regain energies, rethink strategies, and reshape ideological discourses. The ND's co-optation of New Left (NL) themes and tactical support for liberal democracy should be read within the context of this survivalist, "cave dwelling" strategy, as well as the necessity of grappling with the horrors wrought by Fascism.

Fourth, unlike dogmatic guardians of orthodox patterns of thought who see an imaginary fascism everywhere, my aim is not to settle political scores or "hunt fascists", but to show how political ideologies mutate in changing times. It was the French neo-fascist Maurice Bardèche who openly declared his fascism in the post-World War Two era, while arguing that fascism would emerge one day with "another name, another face". ${ }^{31}$ The French neo-fascist insisted that the "famous fascist methods" would be constantly revised to suit changing times. Bardèche influenced the ideological and tactical changes of the revolutionary right, including Alain de Benoist. ${ }^{32}$

Finally, it is important to note that the ND does not work from a fascist tradition per se, but is wedded to an inter-war CR tradition (i.e., Ernst Jünger, Carl Schmitt, and Moeller van den Bruck), which nonetheless provided ideological ammunition for the Nazis in power. ${ }^{33}$ ND leader de Benoist defended Carl Schmitt against a claim in Le Monde that he was a "Nazi philosopher". ${ }^{34}$ In this respect, it should be remembered that Schmitt willingly joined the Nazi Party

\footnotetext{
30) Ibid. Fascism: Comparison and Definition. Madison, Wisconsin: The University of Wisconsin Press, 1980, 174.

${ }^{31)}$ Maurice Bardèche. Qu'est-ce que le fascisme? Paris: Les Sept Couleurs, 1961.

32) Bar-On. Transnationalism and the French 'nouvelle droite'. 2011.

33) Roger Woods. The Conservative Revolution in the Weimar Republic. New York: St. Martin's Press, 1996; Ibid. Germany's New Right As Culture and Politics. 2007.

34) Alain de Benoist. "Schmitt in France". Telos, no. 126 (2003), 133-153. See also: http://www .alaindebenoist.com/pdf/schmitt_in_france.pdf. Accessed January 18, 2012.
} 
in 1933 and acted as its crown jurist. Moreover, Schmitt created a juridical rationale for the "Night of the Long Knives" in which the Sturm Abteilung (SA), the inner paramilitary organization of the Nazi Party, was decapitated through a state terror attack.

\section{Another interpretation of the ND}

In this paper, I offer another interpretation of the ND, which borrows from Roger Griffin's definitions of "ideal type modernism" and "fascism as political modernism". ${ }^{35}$ Contrary to the standard interpretation of the revolutionary right (i.e., CR, Fascism, or ND) as "reactionary modernists" ${ }^{36}$ or "anti-modern Traditionalists", ${ }^{37}$ I argue that the ND operates within a larger modernist revolutionary framework rooted in the $19^{\text {th }}$ and $20^{\text {th }}$ centuries. Most ND thinkers search for an alternative political modernity superseding liberal and socialist meta-narratives about modernity and the "end of history". $3^{8}$

The ND's search for alternative political modernity is rooted in an apparently contradictory bricolage of modern, postmodern, and premodern political and philosophical influences, which Roger Griffin calls "mazeway resynthesis". ${ }^{39}$ Mazeway resynthesis is a term Griffin ${ }^{40}$ borrows from Anthony Wallace, who wrote about revitalization movements and the role of a prophet who seeks to undertake the salvation of a community through an ideological synthesis of ancient and modern ideas. Mazeway resynthesis connotes a syncretic worldview, which emerges in "liminod situations", as a reaction to real or perceived cultural or political crises and the decline of an overarching nomos (i.e., socially created ordering of experience). For both inter-war fascists and the ND, modernity (particularly its political and cultural repercussions) is seen in dark and gloomy terms as destroying Europe's "sacred canopy" of meaning. A "ludic recombination" of worldviews from past, present, and future would help usher in a revolutionary "new beginning" and restore a sense of sacred meaning to the continent and its inhabitants.

\footnotetext{
35) Roger Griffin. "Modernity, modernism, and fascism. A mazeway resynthesis." Modernism/ modernity, 15 (2008) 1, 9-24 ; Ibid. Modernism and Fascism: The Sense of a Beginning under Mussolini and Hitler. New York: Palgrave MacMillan, 2007, 54-55 \& 179-182.

36) Jeffrey Herf. Reactionary Modernism: Technology, culture, and politics in Weimar and the Third Reich. Cambridge, UK: Cambridge University Press, 1984.

37) Umberto Eco. "Eternal Fascism: Fourteen Ways of Looking at a Blackshirt." New York Review of Books, 22 June 1995, 12-15.

${ }^{38)}$ Francis Fukuyama. "The End of History?" The National Interest, 16 (1989) Summer, 3-18.

39) Roger Griffin. "Foreword. Another Face? Another Mazeway? Reflections on the Newness and Rightness of the European New Right," [Foreword to Tamir Bar-On's Where Have All The Fascists Gone?] viii-xvi; Ibid. Modernism and Fascism, 2007; Ibid. Modernity, modernism and fascism, 2008.

40) Ibid. Modernism and Fascism, 105-106.
} 
Those who are opponents of the ND's drive for an illiberal, hierarchical, imperial (yet anti-imperialist), pagan, and internally homogeneous rootsbased "Europe for Europeans" will be tempted to see their project as "reactionary", "archaic", or "antimodern". I insist that viewing the ND as a variant of "reactionary modernism" is a mistake for several reasons. In the first place, the ND as a movement was created in 1968. Thus, ND thinkers digested most of the philosophical and political tendencies which straddle modern and postmodern epochs. To borrow a distinction made by N.J. Rengger , ${ }^{41} \mathrm{ND}$ thinkers both experienced postmodernity as "mood" and saw in the late $20^{\text {th }}$ century the birth of a new "socio-cultural form". "Modernity as mood," Rengger adds, is often "a response within/to the structure of modern life," whereas modernity as "socio-cultural form" emphasizes "the structure of modern life" (i.e., the institutional, social, and economic structures associated with modernity). ${ }^{42}$ In short, ND philosophers have reacted virulently to some of the structures of modern life, while questioning the structures associated with liberal and socialist conceptions of modernity. As the ND "old guard" dies out, postmodern sensibilities, the focus on media and images, diversity and differentiation, and "bottom-up" popular and regional autonomy against the "excesses" of the state, corporate gigantism, and European Union (EU) will only grow in importance. Older themes and debates related to Fascism, Nazism, and even the CR might lose their relevance.

Second, ND intellectuals are certainly against many aspects of the modern and postmodern epochs and they are no cheerleaders of all aspects of globalization, but they also propose concrete modern (or postmodern) solutions for Europe's multiple "ills". These solutions range from alternative models of citizenship and immigration to stem the perceived loss of national and regional identities to post-liberal, modernist models of governance that would allow Europeans to be great geopolitical players in world history again. ${ }^{43}$

Third, leading ND figures might reject political and cultural aspects of modernity (e.g., state-sanctioned legal equality, liberalism, socialism, social democracy, and multiculturalism), but they are not opposed to the technical aspects of modernity. Many ND thinkers are wedded to an alternative modernist framework which is secular, Promethean, technologically activist, economically developmental, and statist (albeit critical of "technocratic" and excessively neo-liberal statism, as well as "technophobia" and "technophilia" $)^{44}$

\footnotetext{
41) N.J. Rengger. Political Theory, Modernity and Postmodernity: Beyond Enlightenment and Critique. Oxford, UK: Blackwell, 1995, 40-45.

${ }^{42)}$ Ibid. 41.

43) Charels Champetier and Alain de Benoist. Manifesto for a European Renaissance. Smithville, Texas: Runa-Raven Press, 2010; Ibid. La Nouvelle Droite de l'an 200o. 1999; Ibid. The French New Right In The Year 2000. 2000. http://home.alphalink.com.au/ radnat/debenoist/alaing.html. Accessed October 31, 2011.

44) Ibid. The French New Right In The Year 2000.
} 
Fourth, ND thinkers make it very clear, particularly in their de facto manifesto, "The French New Right in the Year 2000",45 that there is no way to return to a rural paradise before aspects of modernity "destroyed" the European continent, or to the pre-French revolutionary days when the king was the state. Rather Europe's "way out" of its multiple "crises" will be modern, secular, and revolutionary in that it will supersede liberal or socialist alternatives, while synthesizing the most redeeming features of the modern, postmodern, and premodern epochs. The website of Alain de Benoist ${ }^{46}$ makes this point unambiguously: "Indifferent to contemporary ideological models or fashions, and rejecting all forms of intolerance and extremism, Alain de Benoist also rejects any 'restorationist' nostalgia. When he criticizes modernity, it is less in the name of an idealized past than a preoccupation with postmodern concerns." In the ND worldview of the $21^{\text {st }}$ century, seemingly contradictory CR and New Left ideals mingle in uneasy coexistence seeking to overthrow liberalism along revolutionary lines. ${ }^{47}$

Revolution comes from the Latin word revolutio, meaning a turn around. A revolution is a radical change of the existing political, economic, social, cultural, and institutional frameworks of a society and state. According to Hannah Arendt, ${ }^{48}$ modern revolutions recreate longings conceived in the ancient Greek polis (city-state) in which citizens have "the right and possibility of participating actively in the affairs of the common-wealth." ${ }^{\text {"99 }}$ For Arendt the modern notion of revolution was unknown before the late $18^{\text {th }}$ century liberal revolutions and implies that "the course of history suddenly begins anew. ${ }^{50}$

With ND intellectuals in mind, I propose a broader understanding of revolutions beyond the violent models of 1789 (the French Revolution) or 1917 (the Bolshevik Revolution). It is possible to "examine long-term revolutionary processes with no precise dates, which nonetheless engender profound and radical changes in society, its institutions, and its dominant values." ${ }^{1}$ Contemporary ND thinkers long for their own "Quiet Revolution"52 on the

45) Ibid.

46) http://www.alaindebenoist.com/ Accessed January 20, 2012.

47) Bar-On. Fascism to the 'Nouvelle Droite', 329.

48) Hannah Arendt. On Revolution. London: Penguin, 1963, 21-58.

49) Eric Hobsbawm. Revolutionaries. London: Abacus, 2007, 271.

50) Arendt. On Revolution. 28.

${ }^{51)}$ Tamir Bar-On. "Las Revoluciones En El Mundo. Revolutions in World History." Retos Internacionales, 3 (2010) Fall, 7 .

${ }^{22}$ Revolutions can be "non-violent" as with the "Quiet Revolution" in Québec (Canada) from roughly 1960-66, corresponding to the tenure of Liberal Québec Premier Jean Lesage. The "Quiet Revolution" represented a non-violent revolution in state and societal institutions and mentalities, a turn away from the rural and clerical authoritarianism of the past, and a shift towards modernization, industrialization, secularization, civil rights, nationalist assertiveness, and state involvement in the economy (D.C. Thomson. Jean Lesage et la révolution tranquille. Saint-Laurent, Québec: Éditions du Trécarré, 1984). 
European continent, a "non-violent" revolution against liberalism and socialism that will arise through the triumph of its cultural values in the political realm and the emergence of what Eric Hobsbawm called "an entirely new epoch in human history." ${ }^{33}$ Close to 45 years since its foundation in 1968, the failed revolutionary movement of May 1968 in France is still viewed by ND thinkers as inspirational because it was largely non-violent and demonstrated that "revolution in an advanced industrial country was possible in the conditions of peace, prosperity, and apparent political stability." ${ }^{54}$ While we often equate revolutions with violence, Arendt posited the following: "To be sure, not even wars, let alone revolutions, are ever completely determined by violence." 55

In short, the ND's metapolitical orientation did not mean that it abandoned modernist and revolutionary goals. The ND's quest for alternative modernity should be read as an integral part of the "sense-making" modernist project born of multiple "crises". Griffin defines modernism as "any initiative in the cultural, social, or political sphere which seeks to restore a sense of sublime order and purpose to the contemporary world, thereby counteracting the (perceived) erosion an overarching nomos or sacred canopy under the fragmenting and secularizing impact of modernity. ${ }^{n 6}$

Moreover, Griffin defines fascism in an exhaustive manner, but the first line of the definition is worth quoting: "Fascism is a species of political modernism originating in the early twentieth century whose mission is to combat the allegedly degenerative forces of contemporary history (decadence) by bringing about an alternative modernity and temporality (a 'new order' and a 'new era') based on the rebirth or palingenesis, of the nation., ${ }^{57}$ Griffin also offers a "shorthand definition of fascism": "Fascism is a form of programmatic modernism that seeks to conquer political power in order to realize its totalizing vision of national or ethnic rebirth. Its ultimate end is to overcome the decadence that has destroyed a sense of communal belonging and drained modernity of meaning and transcendence and usher in a new era of cultural homogeneity and health. ${ }^{5} 8$

It is my claim that Griffin's definitions of modernism and fascism can be neatly applied to the ND. The ND seeks to conquer power by winning the battle of ideas in civil society. The French cultural school of thought insists that "ethnic rebirth" can be engineered through the unity of activist elites and the people united against liberalism, socialism, and multiculturalism. Regional,

53) Hobsbawm. Revolutionaries. 269.

54) GRECE, ed. Le Mai 1968 de la nouvelle droite. Paris: Labyrinthe, 1998; Hobsbawm, 307.

55) Arendt, 18.

56) Griffin. Foreword. XII.

57) Ibid. Modernism and Fascism. 181

58) Ibid. 182. 
national, or European preference rather than universalist criteria are promoted by the ND in immigration policies, citizenship laws, welfare benefits, and state support for corporations. For the ND, "ethnic rebirth" is a "totalizing" project because it would ultimately lead to a radical, hierarchical Europe in which non-Europeans are banished from the body politic. For the ND, liberalism leads to societal "decadence" and a loss of meaning because it focuses on individual rights rather than community, ethnic ties, and duties. Furthermore, ND theorists posit that liberalism creates abstract legal citizens wedded to false liberal, universalist principles. Communal belonging, meaning and transcendence, and community health will be restored in a "new era of cultural homogeneity," which abolishes liberal multiculturalism from the European continent and replaces it with a hierarchical, ethnically homogeneous, secular, and revolutionary political order.

Lamenting the "excesses" of the modern world from immigration and multicultural societies to administratively imposed equality and the demise of structured and ethnically homogeneous communities of meaning wedded to a world framed by myth, rituals, and magic, ND thinkers advanced a secular, revolutionary, and modernist framework as an alternative to mainstream liberal and socialist responses to modernity. Moreover, the ND's quest for alternative modernity should be viewed as a "dialectical relationship to modernity, one that entails not the negation of modernity but an attempt to simultaneously abolish, transcend, preserve and transform it." ${ }^{59}$ It therefore follows that alternative modernity entails a radical questioning of modernity, but not the desire to negate or abolish all aspects of modernity. Rather the aim is to create a different type of modernity (alternative modernity) to highlight deep disdain with mainstream liberal and socialist responses to modernity. As a result the ND favours many (yet not all) technical aspects of modernity, but rejects modernity's social, cultural, and political consequences. ${ }^{60}$ Alternative modernity also connotes the questioning of postmodern discourses ${ }^{61}$ which overstate claims of modernity's death, ${ }^{62}$ while ignoring the reality that modernity is the "house" we increasingly all inhabit.

\footnotetext{
59) Roxanne L. Euben. "Premodern, Antimodern or Postmodern? Islamic and Western Critiques of Modernity." The Review of Politics, 59 (1997), 429.

6o) Jürgen Habermas. The Philosophical Discourse of Modernity: Twelve Lectures. Cambridge, MASS.: The MIT Press, 1993; Ibid. The New Conservatism: Cultural Criticism and the Historians' Debate. Cambridge, MASS.: The MIT Press, 1990.

61) J-F Lyotard The Postmodern Condition: A Report on Knowledge. Minneapolis: University of Minnesota Press, 1984.

62) Rengger. Political Theory, Modernity and Postmodernity. 1995; Eugene Lunn. Marxism and Modernism: An Historical Study of Lukacs, Brecht, Benjamin, and Adorno. Berkeley, California: University of California Press, 1982.
} 


\section{The ND as alternative modernity}

In line with my interpretation of the ND's quest for alternative modernity, Ulrich Beck sees the current age not as a "post-modernity" but rather as a "new modernity" ${ }^{\prime 3}$ Beck views the new social movements of the 1990s not as examples of phenomena that stand against modernity, but rather as carriers of the banners of the Enlightenment and modernity in a radicalized tone. The ND is not "antimodern" because they do not fully reject all the processes associated with the Enlightenment and modernity. In short, the ND does not oppose or contradict modernity and its rational and scientific impulses, but instead continues the legacy of modernity in an alternative, revolutionary mode. An astute ND commentator, Paul Gottfried recognized this in a letter to the editor of Commentary about a piece entitled "France's New Right" penned by Robert Kaplan more than 30 years ago. Gottfried argued that de Benoist's "philosophy is unabashedly atheistic and rooted in the Enlightenment's scientific materialism" and points to the ND leader's "attacks" on Christianity as "empirically indefensible and as a hindrance to scientific progress." Gottfried continues the letter by stating that de Benoist's positions are "unusual" for an alleged Pétainiste (supporter of the Nazi collaborationist Vichy regime), although they are "entirely appropriate for a child of the Enlightenment." He concludes the letter by stating that "Mr. Kaplan does not pay sufficient attention to de Benoist's scientific materialism or to GRECE's repeated pleas for Western European unity."64

Moreover, the ND criticizes modernity from a framework that is nonmainstream (i.e., neither liberal nor socialist) in order "to restore a sense of sublime order and purpose to the contemporary world" and counteract the "fragmenting and secularizing impact of modernity." The ND posits a "dialectical relationship to modernity, one that entails not the negation of modernity but an attempt to simultaneously abolish, transcend, preserve and transform it." The ND aims to create a different type of modernity, or alternative modernity, in order to highlight deep disdain with mainstream responses to modernity. Modernity, ND thinkers argue, entails a set of contradictory imperatives whereby the socio-political and cultural effects of modernity (e.g., the notion of "progress", excessive individualism, unrestrained capitalism, egalitarianism, liberalism, neo-liberalism, socialism, communism, multiculturalism, feminism, and gay and lesbian rights) ought to be abolished, while others (e.g., secularism, scientific modes of analysis, economic dynamism, and

\footnotetext{
${ }^{63)}$ Ulrich Beck. Risk Society: Ecological Politics in an Age of Risk. Cambridge, UK: Polity, 1995, 9.

64) Paul Gottfried. "Reader Letters: France's New Right." Commentary (June 1980) https:// www.commentarymagazine.com/viewarticle.cfm/france-s-new-right-13129? page=all. Accessed February 10, 2011.
} 
technological progress) might be maintained or transformed. In short, the ND project both rejects and supports modernity, while seeking to transform and supersede its most destructive aspects in a new ideological synthesis (mazeway resynthesis) consisting of modern, postmodern, and premodern philosophies.

\title{
An "ideal type" modernism
}

Roger Griffin offers an exhaustive and heuristically useful definition of modernism:

\begin{abstract}
"Modernism is a generic term for a vast array of heterogeneous individual and collective initiatives undertaken in Europeanized societies in many spheres of cultural production, social activism, and political militancy from the $19^{\text {th }}$ century onwards. Their common denominator lies in the bid to reinstate a sense of transcendent value, meaning, or purpose in order to reverse Western culture's progressive loss of a homogeneous value system and overarching cosmology (nomos) caused by the secularizing and disembedding forces of modernization. The late $19^{\text {th }}$ century modernists' rebellion against contemporary modernity was shaped by innate predispositions of the human consciousness and mythopoeic faculty to create culture, construct utopias, and to find a subjective access to a superhuman temporality. This faculty is closely bound with the need to belong to a community united by a shared culture which acts as a refuge from the potentially life-threatening fear of personal death bereft of any sort of transcendence. Modernism can assume an exclusively artistic expression, often involving extreme experimentation with new aesthetic forms conceived to express glimpses of a 'higher reality' that throw into relief the anomie and spiritual bankruptcy of contemporary history ("epiphanic modernism"). Alternatively, it can focus on the creation of a "new world", either through the capacity of art and thought to formulate a vision capable of revolutionizing society as a whole, or through the creation of new ways of living or an alternative socio-political culture that will ultimately transform not just art, but humankind itself, or at least a chosen segment of it, under the leadership of a new elite ("programmatic modernism")." ${ }^{6_{5}}$
\end{abstract}

Griffin's definition of modernism is useful for two reasons. In the first place, it helps us comprehend the profound changes taking place in Europe in the late 19th and 2oth centuries, which produced numerous responses to the "crises" of the modern world in differing realms of life from the cultural to the political. Second, I argue that Griffin's "ideal type" definition of modernism is applicable to the ND. Many ND thinkers from Alain de Benoist and Guillaume Faye in France do fit the alternative modernist mould. Faye can be considered the most hyper-modernist of ND thinkers, particularly his idiosyncratic notion "archeofuturism". Faye believes that the Right needs to transcend the old division between those who wish to restore traditions of the past, and those who are calling for new social and technological structures. He calls for a mazeway

${ }_{65}$ Griffin. Modernity, Modernism, and Fascism. 15. 
resynthesis between these two positions, which will unite the most redeeming features of premodern and modern epochs. ${ }^{66}$

\section{"Ideal type" modernism and the ND}

The ND is an example of what Griffin calls "programmatic modernism". "Programmatic modernism" connotes the desire for "the creation of a new world" and "a vision capable of revolutionizing society as a whole." In line with "programmatic modernism", the ND embodies an "alternative socio-political culture that will ultimately transform not just art, but humankind itself, or at least a chosen segment of it, under the leadership of a new elite." The "new elite" is led by Alain de Benoist and a collection of like-minded intellectuals throughout Europe (e.g., Charles Champetier and Guillaume Faye in France, Marco Tarchi in Italy, Michael Walker in England, etc.) seeking to smash the cultural and political legacies of modern liberal societies and "construct utopias" with a "remembrance of things past."

Despite the agnosticism of most ND thinkers, like modernists they recognize that the modern world represented a profound loss for humans in contrast to the structured meaning of premodern religion or spirituality. In his piece "Psychologie du conspirationnisme", de Benoist even dated the rise of conspiracy theories to the acceleration of processes associated with modernity. ${ }^{67}$ For de Benoist and other ND thinkers, political aspects of modernity such as liberalism and multiculturalism are interpreted as a conspiracy to "kill" Europe's "original" ethnic groups. ${ }^{68}$ Historically, the revolutionary and extreme right-wing milieux argued for internationalist Masonic or Jewish conspiracies directed against the "nation", while de Benoist jettisons these "bogus" or "irrational" conspiracies for more empirically rational and defensible conspiracies directed by "liberal-left elites" against "original" European cultures, regions,

66) Guillaume Faye. Archeofuturism: European Visions of the Post-Catastrophic Age. Arktos Media, 2010; Ibid. The Essence of Archaism http://www.counter-currents.com/2010/o7/the -essence-of-archaism/. Accessed January 20, 2011; Ibid. "Mars and Hephaestus : The Return of History." The Occidental Quarterly, 7 December 2009. http://www.toqonline.com/blog/mars -and-hephaestus/. Accessed December 1, 2010; Interview with Guillaume Faye. The Occidental Quarterly, 21 October 2009. http://www.toqonline.com/blog/interview-with-guillaume -faye/. Accessed February 15, 2011; Faye. L'Archéofuturisme. Paris: L'Æncre, 1998; Ibid. "Le traditionalisme: voilà l'ennemi." Lutte du Peuple 32 (1996). http://guillaumefayearchive.wordpress .com/2010/07/09/190/. Accessed February 13, 2011.

${ }^{67}$ ) Alain de Benoist. "Psychologie du conspirationnisme." N.d. http://www.alaindebenoist .com/pdf/psychologie_du_conspirationnisme.pdf. Accessed November 30, 2010.

68) Guillaume Faye. Pourquoi nous combattons. Manifeste de la résistance européenne. Paris: L'Æncre, 2001; Ibid. La Colonisation de l'Europe. Discours vrai sur l'immigration et l'Islam. Paris: L'Æncre, 2000; Ibid. Le Système à tuer les peuples. Paris: Copernic, 1981. 
and nations. In short, the ND views unfettered immigration and multiculturalism as schemes to homogenize, "colonize", and ultimately destroy Europe's rooted cultures. ${ }^{69}$

At the outset, I pointed out that the ND is a loose school of thought born in France. Yet, the ND is also a transnational movement with like-minded intellectuals throughout Europe, which view Europe as the new "common home". One kindered movement of the ND is the Spanish Nueva Derecha (New Right). Modernity, for the authors of a Spanish manifesto influenced by the ND, represents a loss of "identity", "feeling", and "common destiny"; the "death of the spirit"; and the notion the economic represents the most important function in a society whereas traditionally it represented merely a part (usually less valorized) of the social order. ${ }^{70}$ As a result, ND thinkers long "to reinstate a sense of transcendent value, meaning, or purpose in order to reverse Western culture's progressive loss of a homogeneous value system and overarching cosmology (nomos) caused by the secularizing and disembedding forces of modernization." ${ }^{71}$ In step with modernists of previous centuries and globalization's awakening of identities, ND thinkers "need to belong to a community united by a shared culture which acts as a refuge from the potentially lifethreatening fear of personal death bereft of any sort of transcendence. ${ }^{7^{2}}$ For ND thinkers what Griffin calls the "community united by a shared culture" connotes "original inhabitants" of the European continent: white IndoEuropeans devoted to the paganism of their ancestors. If modern liberal societies are becoming devoid of meaning, or worse yet nihilistic, ND theorists have a political programme to "rescue" the continent and its peoples from its current "winter of nihilism". In "The French New Right in the Year 200o", Champetier and de Benoist long for "a radical restructuring" (i.e., a new revolutionary order) of the European continent, which will "exorcise" "anomie and contemporary nihilism". Individualism, egalitarianism, and universalism are viewed as synonyms of a "nihilistic" global capitalism, which is destructive of the "land" and its diverse cultures and undermines the historical and hierarchical ordering of European societies (i.e., political, military, and economic in descending order). ${ }^{73}$ The rediscovery of a common European cultural identity or "common origins" will "rescue" a continent suffering from the "loss of memory" under the fragmenting weight of modernity.

\footnotetext{
69) Ibid. La Colonisation de l'Europe. 2000.

7o) D.L. Sanromán. "Contra la muerte del espíritu: últimos avatares de una Nouvelle Droite a la española." Nomadas, 13 (2006) 1. See: http://www.ucm.es/info/nomadas/13/dlsanroman .pdf. Accessed January 2, 2011.

71) Griffin. Modernity, modernism, and fascism. 15 .

72) Ibid.

73) Sanroman. "Contra la muerte del espíritu".
} 
In order to reconstruct Griffin's definition of modernism, I offer a checklist summary below of the major tendencies of modernism ${ }^{74}$ :

1) A generic term for diverse rebirth movements of the late $19^{\text {th }}$ century onwards in the cultural and political spheres, which reacted to perceived anarchy and cultural decay resulting from the transformation of traditional institutions, social structures, and homogeneous belief systems due to Western modernization processes. These modernizing forces, which transformed material and human relations often in geographically and socially uneven ways, include the following: rationalism, secularization of life, liberalism, capitalism, individualism, egalitarianism, the cult of progress, expanding literacy and social mobility, urbanization, industrialization, rising urban middle (capitalist) and working (rural and proletarian) classes turning away from a feudal structure of society, the growth of representative democracy and bureaucratization, revolutionary changes in communications and transport, geographical discoveries and colonial expansion, the advance of secular science, and powerful technology and "technocracy".

2) A new conception of history and the future, which is "open" to the realization of "utopias". These "utopias" banish the human fear of death devoid of meaning by erecting a revolutionary, "superhuman temporality" against the monotony and meaninglessness of modern and linear historical time.

3) Modernism accelerated momentum in the second part of the 19th century when liberal, capitalist, and Enlightenment myths of progress lost the cultural hegemony they gained during the French Revolution and early Industrial Revolution. Between the 186os and World War Two, modernism was a diffuse cultural force for redemptive social and moral transformation.

4) Cultural and intellectual elites associated modernity with decline, decadence, and degeneration. Modernism unleashed a dialectical process in society based on chaos and new order, despair and hope, decadence and renewal, and destruction and creation. In "programmatic modernism", "the leadership of a new elite" would usher in the radical transformation of humanity or "at least a chosen segment of it."

5) Modernism spawned countless artistic, literary, personal, political, and collective projects to establish a healthier and ethical basis for society, as well as new, radical visions for socio-political order.

6) The new modernist order was often conceived of as an alternative modernity, which sought to end political, cultural, moral, and physical "decline"

74) Griffin. Modernism and Fascism. 45-45; $115^{-117}$. 
and "decadence" through the emergence of a "new man" (or "new woman") and society.

The aforementioned checklist of characteristics of modernism can be applied to ND intellectuals. First, the ND is a rebirth movement, or a modern revitalization movement, with Alain de Benoist its pan-European leader and "prophet", reacting to perceived anarchy and cultural decay resulting from the transformation of traditional institutions, social structures, and homogeneous belief systems due to Western modernization processes. ${ }^{75}$ While de Benoist was once a pro-colonialist with little respect for cultural differences, the loss of French Algeria led the ND doyen to lament the "Westernization of the world" and the perceived destruction of traditional European cultures and non-Western cultures. Born in 1968 long after the first wave of modernists in the late 19th century, the ND focused on "rooted" regionalist, nationalist, and pan-European revivalism through the sphere of "cultural production". Its thinkers railed against the most "decadent" aspects of the modern world, its "cult of progress", its excessive rationalism (or "instrumental reason"), and its fixations on technical solutions for non-technical questions. The loss of "transcendent value, meaning, or purpose" in modern European societies ought to give way to a horizon grounded in "myths" (i.e., principally pagan Indo-Europeanism and "common origins") of pan-European rebirth. ${ }^{76}$

A Manifesto penned by the Spanish Nueva Derecha in El Mundo in $2002^{77}$ attacks a Western civilization based merely on production, consumption, and play; a world where a dominant materialism has supplanted "feeling" and "heart", while producing the "death" of spiritual life and the "disenchantment of the world" without attachment to "land", "values", "destiny", gods, myths, mystery, meaning, aristocratic spirit, and community goals. ${ }^{78}$ Westerners have even forgotten to conceive, adds the manifesto, a world where there are "higher values" than the material, or the empirical world that can be seen everyday. The authors of the aforementioned manifesto entitled El manifesto contra la muerte del espiritu y la tierra (Manifesto against the death of the spirit and the land), Javier Ruiz Portella and Álvaro Mutis, argue that we live in the era of Nietzsche's "last man"; a time of "disorientation" of all realms of life and especially of the "loss" of a "transcendental destiny". As he lived in Belgium for many years, Ruiz Portella is the author of a French-language work, La liberté et sa détresse - ou le désenchantement de la modernité,79 which echoes the

75) Bar-On. "Understanding Political Conversion and Mimetic Rivalry".

76) Champetier and de Benoist. The French New Right.

77) Manifiesto contra la muerte del espíritu y la tierra, El Mundo (2002). http://www.elmanifiesto .com/manifiesto/texto_manifiesto.asp. Accessed February 7, 2012.

${ }^{78)}$ Sanromán. "Contra la muerte del espíritu".

79) J. Ruiz Portella. La liberté et sa détresse - ou le désenchantement de la modernité. Bruxelles:

Éditions Ouisa, 1993. 
Weberian thesis that modernity represents a "disenchantment of the world": A rational, scientific, bureaucratic, and secular understanding of the world, which is more highly valued than belief, myths, or mysticism.

It is no accident that in the post-9-11 climate de Benoist in his piece "Terrorism, State of Emergency", writes that contemporary Westerners "live in a disenchanted world where, for most of the people, nothing is superior to life." De Benoist adds that throughout history "this sentiment has been the exception rather than the rule." He then implies that the 9-11 suicide bombers cannot be conceived of as "absurd nihilists" but "spiritualists" who do not fear death like modern Westerners. The act of "heroic sacrifice" to the community and the myth it engenders in contrast to our contemporary fixation on the here and now appeals to the ND leader. ${ }^{80}$

How do the authors of the aforementioned Spanish manifesto hope to supersede the "nihilism" of the current age and "re-sacralize the world"? They call for greater attention in respect of the ecological crisis, the turn towards art, symbolism, and religion broadly speaking (including "myths" and "magic"), the revival of "mystery" and the "sacred" through paganism, and the creation of popular communities wedded to their specific homogeneous identities. Sanromán rightly points out that paganism is for the Spanish New Right (like the French ND) a type of "civil religion", which restores a sense of "common purpose" (i.e., shared by all the community) and engenders communal myths, as well as structures time, space, and daily life. ${ }^{{ }^{1}}$

Sanromán proposes seven solutions to "re-sacralize" and "re-enchant" modern Europe, which are essentially the same as those proposed by de Benoist in his magnum opus Vu de droite ${ }^{82}$.

1) An aristocratic conception of the human being.

2) An ethics founded on honour (i.e., a focus on shame rather than the Judeo-Christian notion of sin).

3) A heroic attitude towards the challenges of human existence.

4) The exaltation and sacralization of the world.

5) Attention to beauty, the body, and health.

6) The obliteration of notions such as "heaven" and "hell".

7) The union of aesthetics and morality.

\footnotetext{
80) Alain de Benoist. Terrorism, State of Emergency: The pertinence of some Schmittian themes today (n.d.). http://www.alaindebenoist.com/pdf/terrorism_state_of_emergency.pdf. Accessed November 30, 2010. For a different edition see: Alain de Benoist. "Global terrorism and the state of permanent exception: the significance of Carl Schmitt's thought today". In The international political thought of Carl Schmitt : terror, liberal war and the crisis of global order. Eds. Louiza Odysseos and Fabio Petito. London : Routledge, 2007.

81) Sanromán. 'Contra la muerte [...]'

${ }^{82}$ De Benoist. Vu de droite.
} 
The loss of transcendent value, purpose, or meaning is a concern of many cultural and political movements from ecologists and Traditionalists to the ND. Western culture's progressive loss of a homogeneous value system due to secularizing and modernizing forces affects the ND as it did late 19th century modernists such as Charles Maurras or Georges Sorel. For the ND, the materialist, "one-dimensional" nature of modern, secular, and multicultural liberal and socialist societies undermines a primary sense of "duty" to regional and national communities within Europe. In liberal societies, we constantly ask for individual rights, reason ND thinkers, without demanding corresponding duties of citizens in an activist framework. ${ }^{8_{3}} \mathrm{~A}$ liberal, egalitarian society loses its purpose because its members are treated alike under the law. In reality, argue ND thinkers, inequality and hierarchy are "normal" or "natural" and also promote the aristocratic spirit of excellence and self-surpassing, which are necessary for the "health" of any society. Meaning has been lost in liberal societies due to the progressive loss of a homogeneous value system under the weight of secularizing modernity.

Although ND thinkers are largely rational and secular or agnostic, they argue for the necessity of societal myths in order to restore the sacred canopy of community meaning destroyed by the materialism and individualism of modern societies. The myth of internally homogeneous regions and nations attached to the hierarchical, pagan past will be the necessary myth, which restores meaning and pride to Europe's diverse peoples. Dominique Venner, a renowned French historian sympathetic to the ND and a former elite paratrooper in the cause of French Algeria, calls the current age one of "nihilism" in which traditional forms of European identity (dating back 30,000 years ago) have given way to a "false" and "homogeneous" liberal multicultural identity. ${ }^{84}$

Finally, transcendent value will be restored to Europe when it adopts a hierarchical, authoritarian, imperial (yet anti-imperialist), and federal political framework, which challenges liberalism and Western models of modernity and the USA as the world's only remaining superpower. ${ }^{85}$ As history is cyclical for the ND, their thinkers insist that a revolutionary new era will inevitably emerge to undermine the notion that we are "owners and masters" of nature, as well as lead to the "subversion of modernity" in which the trinity of rationalism, equality, and the "disenchantment of the world" reign supreme. ${ }^{86}$

ND philosophers insist that liberal societies have no values save the all-encompassing value of the market's profits. Liberal societies feign moral

\footnotetext{
83) Ibid. "Democracy revisited [...]". 2003; Ibid. Au-delà des droits de l'homme. 2004.

${ }^{84}$ Dominique Venner. Histoire et tradition des européennes: 30 ooo ans d'identité. Paris: Editions du Rocher, 2002.

${ }^{85}$ ) Champetier and de Benoist. "La Nouvelle Droite de l'an 2000". 1999.

86) Sanromán. “Contre la muerte”. 2006.
} 
values, whether the penchant for humanitarian intervention, a "war on terror" in defense of "our" liberal values, cultural equality, family values in Protestant Anglo-American societies, or "freedom" ${ }^{87}$ Yet, the reality is that the moral values of the liberal West are bankrupt, hijacked by the "all-mighty dollar" and the false desire to banish "enemies", conflict, and hence politics from world history. Liberal Western values are merely masks for the "will to power", the "will to technology", or the "will for capital". Moreover, ND thinkers insist that liberal societies lack the spiritual and ritual aspects of premodern societies, which gave life meaning and structure against the "terror of nothingness".

For ND thinkers, the net effect of all modernizing processes is a "totalitarian" model of life, society, and state; the homogenization of world cultures to a "colonial" Western model; and the imposition on diverse societies, cultures, and indigenous peoples a de-humanizing, "ethnocentric" model of progress. What we have gained in the West in economic progress, gadgets, comfort, predictability of life, and the speed of modern life, we have lost in meaning, enchantment, mystery, spiritual awakening, and life purpose. ND theorists point to a perceived contradiction as European societies once provided meaning and a sense of shared belonging through our "rooted" and homogeneous cultural communities, but how can those communities provide meaning when societies around the globe are increasingly forced to think alike and obey the same rhythms of a modern homogenized, liberal, multicultural model?

Second, the ND supports a "new", spherical conception of history and the future, which rejects linear time associated with industrialization, capitalism, and modernity. It also remains "open" to the realization of a utopian, revolutionary, hierarchical, pan-European, and internally homogeneous "Europe of a Hundred Flags", which will revive the mythical community rituals, traditions, and celebrations of premodern pagan Europe within a circumscribed historical time. In a Nietzschean tone, a revolution can occur at any moment in the current modern age of "decadence", which will usher in an era of "rebirth", "cleansing", or "renewal" for European societies. The dawn of a new European springtime of hopes will restore the continent to a mythical, roots-based, "festival time" or "superhuman temporality" where past, present, and future merge. The inauguration of "festival time" would banish the utter alienation and the fear of death of modernity and provide individuals with a shared sense of collective meaning from birth to death.

It is no accident that the authors of the manifesto of the Spanish New Right invoke the German Romantic poet Friedrich Hölderlin (1770-1843): "But where danger is, grows the saving power also." ${ }^{88}$ In turn, the ghost of Hölderlin

87) Alain de Benoist. "Three Interviews with Alain de Benoist." Telos, 98-99 (1993/94) WinterSpring, 173-210.

88) Sanromán. "Contre la muerte". 2006 
resurfaced with exactly the same quotation by the $20^{\text {th }}$ century German philosophical giant and Nazi fellow traveler Martin Heidegger ${ }^{89}$ in "The Question Concerning Technology" in 1953. Hölderlin is cited by Heidegger because despite the "decadence" associated with many aspects of modernity, all is not lost. The Nietzschean "superman" will arise in this hour of greatest "danger", but that "superman" can paradoxically only arise in the "danger" that is the modern world. Moreover, "where danger is, grows the saving power also" connotes that while modernity is indeed "dangerous", it is from its "danger" that will spring a revolutionary new era to usher away the worst "excesses" of modernity. The hour of greatest "danger" is also the time of the "gods" and "titans", to paraphrase a leading thinker of the CR Ernst Jünger - a thinker who markedly influenced de Benoist. ${ }^{90}$ It is the time for the possible "re-enchantment of the world" destroyed by the "decadence" and multiple "crises" of modernity.

Third, modernism accelerated momentum in the second part of the $19^{\text {th }}$ century when liberal, capitalist, and Enlightenment myths of progress lost the cultural hegemony they gained during the French Revolution and early Industrial Revolution. De Benoist ${ }^{91}$ has praised intellectuals within the revolutionary, ultra-nationalist right-wing, prefascist, or French fascist milieu, including Arthur de Gobineau, Gustave Le Bon, Édouard Drumont, Maurice Barrès, Charles Maurras, Robert Brasillach, Henry Montherlant, and Georges Valois. De Benoist ${ }^{92}$ penned a work in the $21^{\text {st }}$ century, which rejected the Rights of Man and the liberal republican heritage of 1789 . These aforementioned revolutionary right-wing thinkers of the late 19th and early 20 th centuries radically questioned the individualist ethos of the French Revolution and the Industrial Revolution's propensity to tear asunder communities. As modernity's materialist and de-territorializing impact cemented in European societies, these right-wing revolutionaries ignited their polemical flames against the modern world. Similarly, while de Benoist has questioned the liberal and socialist "cults of progress" since the 196os, the official demise of the MarxistLeninist Soviet Union in 1991 allowed de Benoist to attack the "myths" of liberalism, neo-liberalism, unrestrained capitalism, the USA, and cultural and political aspects of Enlightenment progress with heightened venom. For the ND from the late 1980 s the "primary enemy" definitively became liberalism rather than the traditional revolutionary right-wing enemy communism.

\footnotetext{
89) Martin Heidegger. Basic Writings. New York: HarperCollins Publishers, 1993, 333.

90) Alain de Benoist. "Soldier, Worker, Rebel, Anarch : an introduction to Ernst Jünger". The Occidental Quarterly, 8 (2008) 3. http://www.alaindebenoist.com/pdf/an_introduction_to _ernst_junger.pdf. Accessed October 31, 2011.

91) Ibid. Vu de droite; Ibid. Bibliographie générale des droites françaises. 2004-2005.

92) Ibid. Au-delà des droits de l'homme.
} 
Fourth, modernity became associated by cultural and intellectual elites in the late 19th and early 20 th centuries with decline, decadence, and degeneration. Yet, modernity also offered visions of "total rebirth", a "new humanity", and "creative destruction". ND thinkers view the Enlightenment, French Revolution, and the processes of modernity in semi-religious terms as the "fall" of European societies from structured meaning, hierarchical order, and rootsbased, community belonging. The decline of European societies, argue ND thinkers, accelerated with the realization of the individualist values of 1789 in Western European liberal societies and reached its peak with the achievement of egalitarian socialist societies in the Soviet Union and states of Central and Eastern Europe. Fascism and communism attempted to stem the tide of decadence and degeneration of European societies, but were woefully unsuccessful and spawned the horrors of totalitarianism. The post-World War Two welfare consensus in Western Europe was increasingly shattered in the mid1980s, while communism officially died with the fall of the Marxist-Leninist Soviet regime in 1991. Contemporary liberal capitalist Europe is again today between a period of decadence and absolute degeneration. Only radically new models of state, society, and economy can rescue Europe's varied cultures and regions from "decadence" and cultural "genocide". These radical models for change would be commandeered by "the leadership of a new elite", which could usher in a re-spiritualized world of "rebirth", if not for all of humanity, then "at least a chosen segment of it" (i.e., "native" or "indigenous" white Europeans and their ancestors).

Modernist movements of the 19th and 2oth centuries oscillated between dialectical polar opposites such as chaos and new order, despair and hope, decadence and renewal, and destruction and creation. They all sought a way out from the perceived chaos, despair, decadence, crisis, and destruction associated with modernity. The old religious and cultural certainties of the premodern era, as well as the hierarchical and cosmic orders of epochs past, were ripped apart by the alienating, fragmenting, and individualist impulses of modernity. Visions of hope, renewal, and creation were offered by the modernists who longed for a new overarching structure of meaning and community order in order to compensate for the loss of meaning of the modern world.

With certain modernists such as Nietzsche, destruction and creation, decadence and renewal, and despair and hope mingled in uneasy coexistence in a "sick" age, which necessitated the "re-evaluation of all values". Similarly, the ND subscribes to a modernist framework, which seeks to destroy the edifice of liberal and Western modernity in order to create a new, polytheistic, hierarchical, and imperial Europe devoted to the "health" of its regions, nations, and Europe. Despair at the depth of the political, spiritual, social, and economic problems plaguing Europe and the prospects of revolutionary change in a postmodern age is coupled with hope that at any moment the revolution (of mentalities and later structures) will take place to rescue Europe from its 
"terminal sicknesses". The problems are compounded for the ND because the "roots" of Europe's decadence are in the egalitarian Judeo-Christian tradition, born thousands of years before the arrival of the modern era. Yet, if Europeans are honest enough to see the scope and breadth of European "decadence", particularly its key elites, they might renew their societies through a revolutionary, modernist framework, which synthesizes the most redeeming features of modern, postmodern, and premodern epochs.

Fifth, between the 186os and World War Two modernism was a diffuse cultural force for redemptive social and moral transformation. Cultural movements as diverse as nudism and vegetarianism, as well as artistic, literary, and political movements on the right, left, and beyond also sought to transcend existing modernity using distinctively modernist lenses and techniques. Nietzsche, Marinetti and the Futurists, Antoine Artaud's Theatre of Cruelty, and Georges Bataille all embodied a modernist ethos, which saw the desires for "authenticity" and "originality" supersede conventions, morality, the JudeoChristian tradition, and the "bourgeois" ethic of order. ${ }^{93}$

The "cult of violence" central to fascist militarization of society, state, and external relations also evoked a modernist desire to raze away the "corrupt" bourgeois order of the past. It promised to: a) restore "transcendent value, meaning, or purpose" to life against the backdrop of decay, anomie, and social breakdown of "actually existing modernity"; b) create a reborn society of "total", new men and women completely devoted to a an alternative conception of modernity, which used the state to rescue the nation and "race" from modernity's "decay" and "decadence". While the ND today gives tactical acceptance to liberal democracy through its metapolitical struggle for "European rebirth", a key source of its identity is its romanticization of German CR thinkers, which embodied a modernist ethos grounded in defense of the "total state", hyper-modern statist mobilization of technology and economic development, and the primary "commitment" of all members of the community to the hierarchical, warrior-based, organic folk community.

Modernism spawned countless artistic, literary, personal, political, and collective projects to establish a healthier and ethical basis for society, as well as new visions for socio-political order. Born in 1968, the ND is merely the latest collectivist, modernist project seeking to establish a "healthy", "virile", elitist, roots-based European political framework through devotion to a strictly cultural project.

CR and "non-conformist" ${ }^{44}$ thinkers of the inter-war era similarly focused on cultural renewal in order to create their visions for a reborn, anti-materialistic,

93) Charles Taylor. The Malaise of Modernity. Concord, Ontario: Anansi Press Limited, 1991, 65-66.

94) John Hellman. The Communitarian Third Way: Alexandre Marc and Ordre Nouveau. 
"spiritual" socio-political order, although CR thinkers such as Carl Schmitt collaborated in legitimizing all the worst excesses of the Nazi state. It is Schmitt who insisted that "he who is sovereign is the one who decides in the case of the exception, but is also sovereign he who decides about the exception itself, that is who decides that it is no longer a normal situation and that the rules no longer apply." In De Benoist "Terrorism, State of Emergency", Schmitt's decisionism became a model for the ND because it highlighted that the realm of the political is based on friends and foes, and that in all regimes (irrespective of ideological colours) decisions must be made in "exceptional" or "emergency" situations (i.e., political or socio-economic crises, insurrections, civil wars, terrorism, etc.), which ultimately restores the hierarchical nature of the sociopolitical order and supplants the legal order. The danger, adds de Benoist following Giorgio Agamben (b. 1942), is "the exception as a permanent norm." It is here that liberal states can become tyrannical like authoritarian regimes. Nonetheless, Schmittian decisionism in the context of a modern, rational, and bureaucratic state is invoked by de Benoist because in a modernist framework "the leadership of a new elite" would usher in the radical transformation of "at least a chosen segment of" humanity.

Sixth, the new modernist order was often conceived of as an alternative modernity, which seeks to end political, cultural, moral, and physical decline through the emergence of a "new man" (or "new woman") and society. The ND searches for an alternative modernity, which seeks to end political, cultural, moral, and physical decline of European societies through the emergence of a "new man", reborn society, and novel models of statecraft. Their intellectuals diagnose the roots of Europe's contemporary ills not only with the modern period, but also the egalitarian Judeo-Christian tradition, which produced processes such as the Enlightenment and modernity, as well as its ideological derivatives liberalism, social democracy, socialism, communism, and feminism. Yet, in seeking to end the current age of "decadence" ushered in by the modern world, with its attendant loss of transcendent and overarching meaning and roots-based, hierarchical communities, the ND calls for an alternative modernity, which differs from mainstream liberal and socialist responses to modernity. The drive for alternative modernity in the post-9-11, postmodern period will "exorcise" the most "unhealthy" aspects of modernity and supersede aspects of the modern world. ${ }^{95}$ Yet, the ND argues that superseding modernity will only occur through the simultaneous recuperation of "premodern" or "antimodern values", as well as technical advances, high-technology

1930-200o. Montreal and Kingston: McGill-Queen's University Press, 2002; Woods. The Conservative Revolution in the Weimar Republic. 1996; J.-L. Loubet del Bayle. Les non-conformistes des années 30 . Paris: Seuil, 1969.

95) Alain de Benoist. "Jihad vs. McWorld." La Padania (19 September 2001). 
telecommunications, economic dynamism, and secular state engineering associated with modernity.

ND thinkers are not outright "reactionaries" in the sense that they do not want to return to the rural world of the log cabin, or the age when the state was the monarch. If we turn to "French New Right in the Year 2000", the ND views the $20^{\text {th }}$ century as the "end of modern times" and the beginning of the postmodern era. The new millennium is marked by the "dictatorship" of liberal globalization and capitalism, but also a return to "tribes" and "networks," the politics of group identities, ecological and quality of life concerns, a turn away from elitism, and generalized social violence. The "New Class" managing liberal globalization still has no answers for both our political problems and search for meaning in an age when "God is dead!" Using ideological mazeway resynthesis, de Benoist and Champetier (1999; 2000) insist that in this century we will turn away from the most corrosive aspects of modernity, using "premodern values" in a postmodern synthesis:

\footnotetext{
"Having nothing new to say, and observing the growing malaise of contemporary societies, the agents of the dominant ideology are reduced to the clichés-ridden discourse so common in the media in a world threatened by implosion-implosion, not explosion, because modernity will not be transcended with a grand soir (a secular version of the Second Coming of Christ), but with the appearance of thousands of auroras, i.e., the birth of sovereign spaces liberated from the domination of the modern. Modernity will not be transcended by returning to the past, but by means of certain premodern values in a decisively postmodern dimension. It is only at the price of such a radical restructuring that anomie and contemporary nihilism will be exorcised. ${ }^{96}$
}

Yet, ND thinkers are not "progressives" in the liberal and left-wing connotations since they have doubts about the political and cultural aspects of modernity, its egalitarian ethos, its understanding of progress, the individualistic and fragmenting nature of modern life, multiculturalism, and the demise of distinctive regional and national cultures to the homogenizing logic of the state and global capitalist market. In an interview with English ND fellow-traveler Troy Southgate for The Occidental Quarterly Robert Steuckers, a Belgian thinker who was part of ND think-tank GRECE until 1993, made this remark which puts him in confrontation with liberalism and socialism: "The principal idea I acquired at a young age was that all ideologies, thoughts or blue prints which wanted to get rid of the past, to sever the links people have with their historical continuities, were fundamentally wrong." 97

96) Champetier and De Benoist. The French New Right In The Year 20oo; Ibid. "La Nouvelle Droite de l'an 2000."

97) Troy Southgate. "Interview with Robert Steuckers." The Occidental Quarterly, 27 March 2010. http://www.toqonline.com/blog/interview-with-robert-steuckers/. Accessed January 3, 2011. 
Nonetheless, the ND shares with Enlightenment-driven liberals and leftists positive faith in reason, science and technology, the mastery of man over nature, and modern, secular models of the ideal state. In line with the modernist political wave of the 2oth century from the Bolsheviks to Franklin Delano Roosevelt's New Deal and the Italian Fascists to the Swedish social democratic state in the post-war era, ND thinkers valorize Isaiah Berlin's notion of "positive liberty".$^{8}$ In contrast to "negative liberty" in which the state is a minimal one and does not generally interfere in the lives of its citizens, the ND calls for "positive liberty: the freedom to select the government of your choice without "New Class" interference. For the ND, an illiberal unified, pan-European state (albeit a regionalist and federally-based state) would act decisively in numerous domains from the economy to the environment and foreign affairs to "free" diverse European ethnic groups from the "shackles" of the contemporary liberal state.

\section{The ND and fascist modernism}

I have pointed out that that the ND is certainly not "reactionary" or "anti-modernist", but rather fits within a modernist framework that seeks an "alternative modernity". It is true that modernists come from all political stripes and that there are left and right-wing forms of modernism. ${ }^{99}$ Julius Evola (1898-1974), ${ }^{100}$ the author of Fascist Italy's so-called "manifesto of spiritual racism", an influence on de Benoist, and a cult hero to the postwar revolutionary right in Italy, is viewed by Griffin as "right-wing form of modernism" with a "futural, palingenetic agenda to erect a new sacred canopy in a decadent world."101

An interesting question that concerns us here is whether ND thinkers can be considered fascist modernists of a right-wing persuasion. I earlier cited Griffin's "shorthand definition" of fascism. At this point, Griffin's full definition of fascism, which I suggest applies to the ND:

"Fascism is a revolutionary species of political modernism originating in the early twentieth century whose mission is to combat the allegedly degenerative forces of contemporary history (decadence) by bringing about an alternative modernity and temporality (a 'new order' and a 'new era') based on the rebirth or palingenesis, of the nation. Fascists conceive the nation as an organism shaped by historic, cultural, and in some cases, ethnic and hereditary factors, a mythic construct incompatible with liberal, conservative, and communist theories of society. The health of this organism they see undermined as much by the principles of institutional and cultural pluralism, individualism, and globalized consumerism promoted by liberalism as by the global regime of social justice and human

${ }_{98)}$ Isaiah Berlin. Four Essays on Liberty. Oxford: Oxford University Press, 1969.

99) Griffin. Modernism and Fascism. 137-138.

${ }^{100)}$ Julius Evola. Revolt Against the Modern World. Rochester, Vermont: Inner Traditions, 1995.

101) Griffin. Modernism and Fascism. 138. 
equality identified by socialism in theory as the ultimate goal of history, or by the conservative defence of 'tradition."'102

Moreover, Griffin points out that fascists seek to overcome the current age of "decadence", erect a new canopy of sacred meaning based on "national or ethnic rebirth" and "cultural homogeneity", and usher in an age of "communal belonging", "meaning and transcendence" (which have been "destroyed" by the alienating tendencies of modernity). ${ }^{103}$

If we apply Griffin's definition to the ND, we can conclude the following:

1) The ND is both modernist and fascist.

2) It sees most of contemporary Europe, especially the EU as it is currently constituted, as "decadent" because of the reigns of liberalism, egalitarianism, multiculturalism, and capitalism.

3) It rejects socialism, communist, or social democracy because they share with liberalism an egalitarian view of human beings, thus undermining the importance of elite rule and hierarchical societies.

4) Conservatism is also rejected because what Europe requires is a revolutionary new political order. This revolutionary political order will usher in a postliberal, alternative modernity consisting of a synthesis of sometimes incompatible ideals from past, present, and future (mazeway resynthesis).

5) The "new era" is based on a mythical notion of national, regional, and European rebirth: pre-Christian, Indo-European paganism. This "new era" would restore "cultural homogeneity" (homogeneous states) to Europe, erect a Europe of a hundred internally homogeneous states flags, and create a new model of citizenship in which non-Europeans would be banished from the body politic.

6) The "new era" would be a re-spiritualized age of "communal belonging" based on duties to your region, nation, and Europe rather than individual rights. A sacred canopy of meaning would be restored to Europe in contrast to the alienating and individualistic processes associated with many aspects of modernity.

An examination of the ND's "The French New Right in the Year 2000" highlights the degree to which it conforms with Griffin's aforementioned definition of fascism and an alternative modernist framework. ${ }^{104}$ In section 1 of the

\footnotetext{
102) Ibid. 181.

103) Ibid. 182.

104) For a thorough analysis of the manifesto, see Tamir Bar-On, "Intellectual Right-Wing Extremism - Alain de Benoist's Mazeway Resynthesis since 200o." In The Extreme Right in Europe: Current Trends and Perspectives. Eds. Uwe Backes and Patrick Moreau. Gottingen: Vandenhoeck and Ruprecht, 2012, 333-358.
} 
manifesto, the authors de Benoist and Champetier imply that various European ethnic and regional communities have been undermined by a "foreign" JudeoChristian tradition, which attacks Europe's polytheistic, hierarchical pagan religions of the past. Mythical rebirth will be grounded on a return to "common origins" based on ethnic criteria rather than liberal, civic models of belonging. Contemporary liberal European "decadence", alienation, and the lack of a sacred canopy of meaning will be superseded, write the authors, in a unique ideological synthesis (mazeway resynthesis): "Modernity will not be transcended by returning to the past, but by means of certain premodern values in a decisively postmodern dimension. It is only at the price of such a radical restructuring that anomie and contemporary nihilism will be exorcised." The authors point out that the acceleration of the "end of ideologies" phenomenon in the post-Cold War, "post-communist" context simultaneously fuels a political crisis and crisis of meaning. They reject conservatism, as well as liberalism and Marxism, because they are mirror, materialistic, and "totalitarian" ideologies.

Despite the ND's valorisation of cultural ethnopluralism based on a Herderian influence, the ND does not jettison outdated biological notions of cultural belonging. In section 2 of the manifesto, in a passage that would make the liberal-left shiver, the ND authors write: "To the extent that life is generated above all through the transmission of information contained in genetic material, man is not born like a blank page." De Benoist and Champetier add that "modernity has not liberated man from his original familial belonging or from local, tribal, corporative or religious attachments." As a result, they argue that "only a return to communities and to a politics of human dimensions" would undermine the lack of social bonds, reification caused by capitalism, and the proliferation of abstract juridical regulations of the state, supranational organizations, and corporations, which invade all aspects of our modern lives. In section 2, the authors point out that they believe "the return of the sacred will be accomplished by the returning to some founding myths." This founding myth will be centred on a regional or national ethnos within a panEuropean, federal framework. The myth will challenge the "disenchantment of the world" and the turn away from the sacred spawned by modernity. "The French New Right is imbued with a very long memory: it maintains a relation to the beginning that harbors a sense of what is coming," adds the manifesto. This would mean a "long memory" for pagan Indo-European origins buried by the Judeo-Christian tradition and its modern, egalitarian liberal and socialist secular derivatives. Rejecting liberal and socialist variants of progress and linear time, the authors view present and future but "permanent dimensions of all lived moments."

Section 3 of the manifesto highlights ND positions on contemporary problems. Rejecting immigration as a culturally detrimental force for both "host" 
and "home" societies, they call for the end of immigration to the continent and the re-evaluation of civic, liberal, and non-racial models of citizenship. Yet, unlike the anti-immigrant French Front National (FN - National Front), they blame capitalism rather than immigrants for problems associated with immigration: "The responsibility for current immigration lies primarily, not with the immigrants, but with the industrialized nations which have reduced man to the level of merchandise that can be relocated anywhere." In section 3 , the ND pines for direct democracy along ethnic or racial lines: "The essential idea of democracy is neither that of the individual nor of humanity, but rather the idea of a body of citizens politically united into a people." People here does not imply all the people (demos), but a circumscribed, homogeneous people along rooted ethnic lines. Is this not a disguised form of racism? In order to counter charges of racism, the ND manifesto states:

"For the New Right, the struggle against racism is not won by negating the concept of races, nor by the desire to blend all races into an undifferentiated whole. Rather, the struggle against racism is waged by the refusal of both exclusion and assimilation: neither apartheid nor the melting pot; rather, acceptance of the other as Other through a dialogic perspective of mutual enrichment."

In short, it is easy to be against apartheid in the $21^{\text {st }}$ century, yet the ND is here supporting a heterogeneous Europe cleansed of ethnic non-Europeans within its homogeneous regions or nations. The ND's rejection of the "melting pot" is an attack on both the purported state assimilationist policies of the USA and France. The ND's multiculturalism of the right is designed to open greater public spaces for "indigenous" Europeans, while invoking referenda on issues such as immigration in order to block immigrants from non-European source countries. The implicit argument of the ND is that in the new millennium France has become the colony of uncontrolled immigration, the new Algeria is mainland France, and perhaps the "common sense" of the people united in the framework of an ethnos can vote to democratically reverse this "ethnocidal" project destructive of Europe's pagan past and historic regions and nations.

\section{Modernist models of the past}

ND thinkers are not trail-blazers in calling for alternative modernities. While those on the liberal-left might have ideological bones to pick with the

${ }^{105)}$ A term distinctive from genocide inspired by French ethnologist Robert Jaulin (1928-96) used by ND thinkers to connote the destruction of the culture of a people. See, for example, Guillaume Faye, Le système à tuer les peoples. Paris: Copernic, 1981. 
ND, the modernist credentials of its thinkers are indeed profound. The ND could draw on modernist revolutionary models from the past, including the agnostic secularism of Charles Maurras, German CR thinkers, fascist modernizers such as Mussolini and Hitler, and even revolutionary left-wing modernists such as Lenin and Stalin or right-wing modernists such as Evola and today's Dugin. All of these diverse political tendencies longed for alternative modernities as a response to the "disenchantment of the world" produced by the rise of an "alienating" modernity. They all understood that modernity ushered in broad societal changes, anomie as religious and rural-based homogeneous community values declined, and the loss of a sacred canopy of meaning. These modernists spanning political movements from the right to left all saw the necessity of new, mythical, modern, and secular political projects, which restored community belonging and meaning in an age rife with unrestrained egoism. Each age necessitated its own solutions, as the "dictatorship" of modern values accelerated. Yet, those solutions could only be revolutionary if they created a radical, new political order by integrating elements of the modern world. The ND's eclectic ideological mazeway resynthesis did exactly this by synthesizing modern, postmodern, and premodern philosophies.

Modernism was a shared reality that particularly affected the European continent in the period of multiples crises between the two world wars. Griffin pointed out how Mussolini and Hitler longed for a new historical beginning using novel, modern models of the state and economy to end the "decadence" of the inter-wars years and restore a sense of sacred meaning to Italians and Germans purportedly destroyed by the alienating aspects of the modern world and the egalitarian legacy of the French Revolution. ${ }^{106}$ In his Modernity and the Holocaust, Baumann analyzed the Nazi "gardening state", which used goaloriented, modernist, bureaucratic, and distancing techniques in the service of the mythical Aryan race during the butchery of the Final Solution against the Jews and other "non-Aryans" ${ }^{107}$ Kallis insists that modernizing, exterminationist techniques were part of a pan-European drive in the inter-war years, which reached their dizzying apogee in Nazi Germany in the $1940 s .{ }^{108}$ Turda highlights the history of eugenics, which found its culmination in the Nazi policies of genocide, but was also as an integral part of European modernity in which the state and the individual sought to create an idealized national

106) Griffin. Modernism and Fascism.

107) Zygmunt Bauman. Modernity and the Holocaust. Ithaca, New York: Cornell University Press, 1989 .

108) Aristotle Kallis. Genocide and Fascism: The Eliminationist Drive in Fascist Europe. London: Routledge, 2009. 
community. ${ }^{109}$ Weller argues that the most influential strains of philosophical, political, and aesthetic modernism grow out of the conviction that modernity is nihilistic. He points out that an understanding of modernism and postmodernism is impossible without reflecting about the notion of modernity as nihilistic. $^{110}$ Gregor has demonstrated how the leading theoreticians of Italian Fascism longed for "developmental dictatorship" in order to rescue Italy from economic "backwardness". ${ }^{111}$ In another work, Gregor argues that fascist intellectuals such as Giovanni Gentile and Benito Mussolini were just as "rational" and "modern" as their liberal or leftist counterparts in their solutions for Europe's perceived ills in the early $20^{\text {th }}$ century: "However Fascism is judged by history, the movement, the revolution, and the regime itself had, at their disposal, as talented and moral a cadre of intellectuals as any found in the ranks of revolutionary Marxism or traditional liberalism." ${ }^{\text {112 }}$ Roberts has shown how totalitarianism was a modernist drive shared by the Marxist Leninist Soviet Union, Fascist Italy, and Nazi Germany. ${ }^{113}$

Yet, without doubt ND thinkers are most indebted to the CR and its Nietzschean shadow in their search for alternative modernities. While CR thinkers glorified the organic folk community and German ultra-nationalism, they were hyper-modern in their valorization of the worker and soldier as models of the new, revolutionary, authoritarian collectivist state. For Jünger, the figure of the worker embodied the glories of socialist collectivism, while the soldier helped to create a rising ultra-nationalist tide based on the "blood socialism of the trenches". In the figure of the soldier, Jünger saw no bourgeoisie or proletariat, the two sectors of society thought to be in a titanic class struggle according to traditional Marxist theory. In the worker, Jünger saw the possibilities of total devotion to the metaphysical glories of the state and nation. In the soldier and worker, Jünger invoked the modern possibility to synthesize the most redeeming features of socialism with those of ultranationalism in the service of the folk nation and state. Economic dynamism and technological development would be utilized to create a revolutionary, ultra-nationalist warrior-worker state. ${ }^{114}$

\footnotetext{
109) Marius Turda. Modernism and Eugenics. Basingstoke, UK: Palgrave MacMillan, 2010.

11) Shane Weller. Modernism and Nihilism. Basingstoke, UK: Palgrave Macmillan, 2010.

ii) A. James Gregor. The Faces of Janus: Marxism and Fascism in the Twentieth Century. New Haven, CT: Yale University Press, 2000.

112) A. James Gregor. Mussolini's Intellectuals: Fascist Social and Political Thought. Princeton: Princeton University Press, 2004, 17.

${ }^{113}$ ) D.D. Roberts. The Totalitarian Experiment in Twentieth-Century Europe: Understanding the poverty of great politics. New York: Routledge, 2006.

14) De Benoist. "Soldier, Worker, Rebel, Anarch."
} 


\section{Conclusion}

This paper began by examining whether the ND is fascist. Most of the maximalist definitions of fascism utilized argued that the ND had some but not all the characteristics of fascism. I then utilized Griffin's "ideal type" definition of modernism and fascism, which was applied to the ND. I argued that ND thinkers are a transnational network of thinkers, who long for a revolutionary, panEuropean alternative modernity which is neither liberal nor socialist. In addition, I demonstrated how modern right-wing and left-wing movements of the past were also rooted in a modernist framework. While the ND rejects political and cultural aspects of the modern world, the Enlightenment legacy, and French Revolution, they remain rooted to a modernist worldview. The ND's modernist worldview valorizes limited faith in "instrumental reason", scientific and technological progress, the modern, secular state apparatus, the "dialogical character" of mutual cultural recognition, and the "ethic of authenticity" ("being oneself"). ${ }^{115}$ The ND's version of the "ethic of authenticity" would solve the ills of modern society by harkening back to mythical, "rooted", "original", and "homogeneous" pagan European communities of belonging, while synthesizing the most redeeming features of the modern and postmodern epochs (mazeway resynthesis). The ND seeks an alternative modernity, which will be achieved through what Griffin called a "ludic recombination" of seemingly incompatible political and philosophical ideas.

I also pointed out that the ND's alternative modernist framework is indeed revolutionary. The metapolitical approach of ND thinkers should not obfuscate the reality that ND theorists seek a "radical restructuring" of the political, economic, social, and cultural institutions throughout Europe, as well as the emergence of radically novel human beings wedded to a new and re-spiritualized epoch in human history. As Champetier and de Benoist argue, the worst aspects of modernity will be "transcended" through a "radical restructuring" which will banish "anomie and contemporary nihilism." In proposing a revolution from the right, ND thinkers are wedded to a modern, secular, and utopian conception of politics, which ironically has its roots in the egalitarian American and French Revolutions they want to abolish. Nonetheless, the ND rejects the former revolutions because they connote "decadent" trends associated with modernity such as egalitarianism and the "abstract religion" of individual rights above duties to one's ethnic communities and ancestors.

${ }^{15)}$ Charles Taylor. The Malaise of Modernity. Concord, Ontario: Anansi Press Limited, 1991, 65-66. 
ND doyen de Benoist insists that what he proposes is not a counter-revolution, a return to the monarchical system before the French Revolution, but rather a revolution in mentalities and values which will ultimately produce a new, revolutionary political and social system that destroys liberalism and neo-liberalism. While the "social question" was fundamental for the French Revolution, it was not as critical for the American Revolution where "freedom" and "rights" became the revolutionary watchwords. ${ }^{116}$ For the ND, the "social question" is reformulated to connote: 1) a duty to take care of one's "own" European ethnic groups above all other ethnic groups or cultures in citizenship, jobs, housing provisions, state welfare services, and corporate support (i.e., regional, national, or European preference and the goal of an ethnocracy based on the legal, political, economic, and cultural dominance of "original" Europeans above non-Europeans) $)^{117} ; 2$ ) a critique of neo-liberalism because of its tendency to exacerbate social conflicts; and 3) co-optation of New Left themes, which are critical of the most harmful aspects of global capitalism, liberalism, and socialist state engineering. Yet, the ND did not view the "social question" from communist and socialist lenses because the aforementioned economic and political systems are based on the principle of equality, which must be "destroyed" because it contradicts elite rule, nature, and Europe's "rooted" and imperial past.

Aware of the changing geopolitical fortunes of Europeans, who were once the key players in history with colonial possessions spanning the globe, the ND is engaged in a process of reshaping hearts and minds with the aim of restoring the European continent to its past glories. The ND's long-term historical memories are of a Europe at the centre of international affairs: British, French, Dutch, and Spanish colonialism, the Holy Roman Empire, the Hapsburg Empire, and the Roman Empire. The ND seeks to gather a coalition of forces that would challenge the USA's impressive "empire" in spanning all the oceans of the globe and other potential rivals to its eastern frontiers in Asia. Yet, the ND is conscious that we live in a postmodern, "anti-imperial" or "postimperial" age where one cannot rule others through force or in contravention of the principle of self-determination. ${ }^{118}$ Hence the ND's valorization of the "right to difference" of homogeneous cultural communities worldwide and constant refrains against the homogenizing logic of globalization, liberalism, capitalism, and multiculturalism, all viewed as variants of "cultural imperialism".

\footnotetext{
116) Arendt. On Revolution. 59-140.

117) Nils A. Butenschøn. Politics of Ethnocracies: Strategies and Dilemmas of Ethnic Domination. Oslo : Institutt for Statsvitenskap, Universitetet i Oslo, 1993.

18) Michael Ignatieff. "The American Empire: The Burden" The New York Times Magazine, January 5, 2003.
} 
As European identities are in flux, the ND model of identity has shifted dramatically to suit changing times. In the 196os Alain de Benoist was a supporter of the colonial project of French Algeria and the "burden of the white man". Today de Benoist is a "democrat" and for the "right to difference" of cultures worldwide. ${ }^{119}$

The European continent is a site of contestation for competing models of identity. It is true that the EU has played a major role in shaping those identities, but the scepticism surrounding the EU in Denmark, France, Ireland, and other sovereign states suggests that the identity question is never definitively closed. As the wars in Afghanistan and Iraq show, Europe has not fully created a united foreign policy, a key goal of the ND.

To the question of "who are we?", ND thinkers reply that they are simultaneously pagan Europeans, as well as members of internally homogeneous regions and nations with their distinctive histories, institutions, traditions, and rituals. Political and cultural aspects of modernity are viewed as corrosive to the shared sense of community meaning inherited from premodern European societies. A political revolution will come to Europe, argues the ND, because there will first be a revolution in values. Aspects of modernity, insist the ND, will produce the seeds of its own destruction. A revolutionary, hierarchical, imperial (yet anti-imperialist), and illiberal political order will "save" the European continent, argue the ND.

I pointed out that Martin Heidegger, the German philosophical giant of the $20^{\text {th }}$ century and a Nazi fellow traveler, wrote: "Where grows the greatest danger, there also grows the saving power"? The ND leader, Alain de Benoist, is no Nazi fellow traveler, but like Heidegger he sees a modern world impregnated with "danger", "crises", "decadence", and "decay". His solutions to "rescue" the continent from the self-inflicted "ethnocide" (genocide) of its "original peoples" borrow from politically correct New Left, Green, and direct democracy positions. Yet, neither liberal nor socialist, the ND's quest for alternative modernities is profoundly revolutionary in that it conceives of "a wholescale political change in which men are conscious of introducing an entirely new epoch in human history." Should the ND project be adopted it would lead to the "death of 1789" and the pain of homelessness for millions of Europeans which reject this project, or are deemed "non-Europeans". The $21^{\text {st }}$ century and its "crises" will be the ND's opportunity, as well as all opponents of liberalism worldwide, to bury liberalism.

19) De Benoist. “Democracy revisited.” Tusum qua consil hae tabunum diis. 